\title{
Case Load of Placenta Previa and Accreta at Assuit Women's Health Hospital: Maternal and Neonatal Outcomes
}

\author{
MAHMOUD S. ZAKHERAH, M.D.; ESSAM R. ABD EL-HAFIZE, M.D. and MERVT A. MOHAMED, M.Sc. \\ The Department of Obstetrics and Gynecology, Faculty of Medicine, Assuit University, Egypt
}

\begin{abstract}
Background: Placenta previa and accreta is considered a severe pregnancy complication that may be associated with massive and potentially life-threatening intrapartum and postpartum hemorrhage, so it has become one of the most important leading cause of emergency hysterectomy which represents $40-60 \%$ of cases. Maternal morbidity had been reported to occur in up to $60 \%$ and mortality in up to $7 \%$ of women with placenta accreta. Also the additional potential intra operative and post-operative morbidity were associated with massive blood transfusion, hypovolymea, surgical injury to the ureters, bladder, bowel, or neurovascular structures; adult respiratory distress syndrome, need for blood transfusion, electrolyte imbalance, renal failure and infection.
\end{abstract}

Aim of Study: The aim of the current study was to define the prevalence of placenta previa and accreta in the period from January 2016 to December 2016 and to evaluate the maternal and neonatal outcomes.

Patients and Methods: The study design was a retrospective descriptive study from recorded data in the period from January 2016 to December 2016 on all patients delivered at Women's Health Hospital, Assuit University including all cases of placenta previa with or without placenta accretta, maternal and neonatal data was evaluated. Finally, the obtained data was analyzed by means of SPSS software (Version 16.0) and $p<0.05$ was taken as the significant level.

Results: Total number of deliveries 13486 cases the incidence of placenta previa was 267 cases $(1.98 \%)$, also the incidence of placenta accreta was 55 cases $(0.4 \%)$, uterine artery ligation in 166 cases $(62.1 \%)$, placenta left in situ in one case $(0.37 \%)$, intra uterine balloon insertion in 6 cases $(2.25 \%)$, transverse B Lynch in 10 cases $(3.75 \%)$, internal iliac artery ligation in 4 cases $(1.5 \%)$, cesarean hysterectomy was performed in 37 cases $(13.8 \%)$, bladder injury occurred in 33 cases $(12.4 \%)$, ureteric injury in 3 cases $(1.1 \%)$, colon injury in one case $(0.37 \%)$, vascular injury occurred in one case $(0.37 \%)$, post partum internal hemorrhage occurred in 3 cases $(1.1 \%)$, post partum pelvic hematoma occurred in one case $(0.37 \%)$, ICU admission was needed in 20 cases $(7.5 \%)$, post-operative blood transfusion was needed in 62 cases

Correspondence to: Dr. Mahmoud S. Zakherah, The Department of Obstetrics and Gynecology, Faculty of Medicine, Assuit University, Egypt
(23.2\%), re intervention needed in 8 cases $(2.9 \%)$, maternal mortality was 4 cases $(1.5 \%)$, the mean gestational age was $34.73 \pm 2.8$ weeks. Also there were 66 neonatal cases $(22.1 \%)$ needed assisted ventilation in the form of ambu bag or endotrachial intubation gestation. NICU admission needed in 41 neonatal cases $(15.4 \%)$, and neonatal mortality reported in 7 neonatal cases $(2.6 \%)$. Congenital anomalies were reported in 2 neonatal cases $(0.7 \%)$.

Conclusion: The incidences of placenta previa and placenta accreta were higher than which reported internationally due to increase CS rate. Also there is no definite planned management method widely accepted except for hysterectomy.

Key Words: Placenta previa-Accrete-Neonatal outcomes.

\section{Introduction}

PLACENTA previa and placenta accreta is considered a severe pregnancy complication that may be associated with massive and potentially lifethreatening intra partum and postpartum hemorrhage [1], so it has become one of the most important leading cause of emergency hysterectomy which represents $40-60 \%$ of cases [2], also that may be lead to surgical injury to the ureters, bladder, bowel, or neurovascular structures; adult respiratory distress syndrome; acute transfusion reaction; electrolyte imbalance; and renal failure. The average blood loss at delivery in women with placenta accreta is $3,000-5,000 \mathrm{~mL}$. As many as $90 \%$ of patients with placenta accreta require blood transfusion, and $40 \%$ require more than 10 units of packed red blood cells. Maternal mortality with placenta accreta has been reported to be as high as $7 \%$. Maternal death may occur despite optimal planning, transfusion management, and surgical care [3]

Placenta previa complicates approximately $0.4 \%$ pregnant women [4] and has a mortality rate of $0.03 \%$ [5] 
In the period of 1982-2002, researchers have reported the incidence of placenta accreta as 1 in 533 deliveries [6]. The marked increase in the incidence has been attributed to the increasing prevalence of cesarean delivery in the recent years.

The incidence of prenatal complications is also increased mainly due to preterm birth and small for gestational age fetuses [7], also the incidence of RDS in infants delivered at 30-35 weeks gestation by cesarean section was significantly higher in mothers with placenta previa than in women without placenta previa [8]. Placenta previa also was weakly but significantly associated with an increased risk of major congenital anomalies [9].

\section{Patients and Methods}

\section{Setting:}

The study was conducted at Women's Health Hospital, Assiut University.

\section{Subjects:}

All cases delivered at Women's Health Hospital Assiut University from January 2016 to December 2016 including all cases of placenta previa with or without placenta accreta.

\section{Study design:}

It is a retrospective descriptive study from available data, all cases was evaluated as regrdes history and examination, ultrasound report, vaginal ultrasound report if done, doppler if done to knew if there is abnormal placentation as placenta accreta and its degree, hemoglobin and platelets levels before delivery.

\section{Maternal outcomes:}

\section{A- Intra-operative:}

Type of cesarean section, amount of blood loss during the procedure, need for blood transfusion and type and amount of blood products, presence of abnormal placentation (accreta \& increta or percreta), injury to nearby structures as bladder \& colon or ureter \& vascular injury, hysterectomy if done: Total or subtotal, the need for additional surgical step as (uterine artery ligation, intra uterine balloon insertion, transverse B-Lynch. Radiological intervention (IIAE), leave placenta in situ.

\section{B-Post-operative:}

Post-operative hemoglobin, post partum hemorrhage. Post partum pelvic hematoma, ICU admission, need for blood transfusion, need for second operation, DVT or pulmonary embolism, post- operative infection, maternal mortality, postoperative duration of hospital stay.

\section{Neonatal outcome:}

Gestational age at termination, birth weight, Apgar score at 1 minute and after 5 minutes, the need for assisted ventilation, congenital anomaly, NICU admission, neonatal mortality.

\section{Statistical analysis:}

Gathered data was processed using Statistical Package of Social Sciences Version 16.0 (SPSS Version 16.0 Inc., Chicago, IL, USA). Quantitative data was expressed as means \pm Standard Deviation (SD) as appropriate. Qualitative data was expressed as frequency (numbers) and percentages. The results for all categorical variables were given in the form of rates (\%). Student $t$-test was used to test significance of difference for quantitative variables that follow normal distribution. Chi Squares and Fishers Exact tests were used to test significance of difference for qualitative variables. The independent data of the study was conducted and analyzed. A probability value ( $p$-value) $<0.05$ was considered statistically significant.

\section{Results}

Table (1): Incidence of placenta previa and accreta in relation to total number of deliveries over the two years.

\begin{tabular}{ll}
\hline & No \& \% \\
\hline Total number of deliveries & 13486 \\
Number of cases of placenta previa & $267(1.98 \%)$ \\
Number of cases of placenta accreta & $55(0.4 \%)$ \\
\hline
\end{tabular}

Table (2): Intra operative data of the studied patients over the two years.

\begin{tabular}{lll}
\hline & \multicolumn{1}{c}{ No \& $\%$} \\
\hline Additional surgical step: & & \\
$\quad$ Uterine artery ligation & $166(62.1 \%)$ \\
Leave placenta in situ & 1 & $(0.37 \%)$ \\
Intra uterine balloon insertion & 6 & $(2.25 \%)$ \\
Transverse B Lynch & 10 & $(3.75 \%)$ \\
Radiological intervention (*IIAE) & 4 & $(1.5 \%)$ \\
Cesarean hysterectomy: & 37 & $(13.86 \%)$ \\
Blood transfusion & $250(94 . \%)$ \\
Injury to nearby structure: & \multicolumn{2}{l}{$(1.1 \%)$} \\
Bladder injury & $33(12.36 \%)$ \\
Ureter & 3 & $(1.37 \%)$ \\
Colon & 1 & $(0.37 \%)$ \\
Vascular injury & 1 & $(0.37 \%$ \\
\hline
\end{tabular}

*IIAE: Internal Iliac Artery Embolisation. 
Table (3): Post-operative data of the studied patients over the two years.

\begin{tabular}{|c|c|}
\hline $\begin{array}{l}\text { - Post-operative hemoglobin (mean } \pm \text { SD) by } \\
\text { gm/dl. }\end{array}$ & $9.47 \pm 1.25$ \\
\hline -Atonic POST-partum hemorrhage (no \& \%). & $1 \quad(0.37 \%)$ \\
\hline - Post-partum internal hemorrhage (no \&\%). & $3 \quad(1.12 \%)$ \\
\hline - Post-partum pelvic hematoma (no \& \%). & $1 \quad(0.37 \%)$ \\
\hline - Blood transfusion post-operative (no \& \%). & $62(23.22 \%)$ \\
\hline - ICU admission (no \& \%). & $20(7.49 \%)$ \\
\hline - Post-operative infection (no \& \%). & $0 \quad(0.0 \%)$ \\
\hline $\begin{array}{l}\text { - Post-operative pulmonary embolism (no \& } \\
\% \text { ). }\end{array}$ & $0 \quad(0.0 \%)$ \\
\hline $\begin{array}{l}\text { - Re-intervention (no \& \%): } \\
\text { - Just exploration } \\
\text { - Transverse B Lynch } \\
\text { - Intrauterine balloon insertion } \\
\text { - Internal iliac artery ligation } \\
\text { - Hysterectomy } \\
\text { - Urological intervention } \\
\text { - Internal iliac artery embolization + } \\
\text { hysterectomy } \\
\text { - Secondary suture }\end{array}$ & $\begin{array}{l}8(2.9 \%) \\
2(0.74 \%) \\
1(0.37 \%) \\
1(0.37 \%) \\
1(0.37 \%) \\
2(0.74 \%) \\
1(0.37 \%) \\
0(0.0 \%) \\
0(0.0 \%)\end{array}$ \\
\hline $\begin{array}{l}\text { - Post-operative duration of hospital stay (mean } \\
\pm \text { SD) by days. }\end{array}$ & $3.34 \pm 3.13$ \\
\hline - Maternal mortality (no \& \%). & $4(1.5 \%)$ \\
\hline
\end{tabular}

Table (4): Neonatal data of the studied patients over the two years.

- Birth weight (mean \pm SD) by grams

$2758.8 \pm 554.09$

- Apgar score at 1 min. (mean \pm SD) by $7.83 \pm 2.81$ number

- Apgar score 5mins. (mean \pm SD) by number $8.96 \pm 2.39$

- Assisted ventilation (No \& \%)

$61(22,8 \%)$

- *NICU admission (No \& \%)

$109(22.1 \%)$

- Congenital anomalies (No \& \%)

$5(1.0 \%)$

- Neonatal mortality (No \& \%)

$18(3.6 \%)$

*NICU: Neonatal Intensive Care Unit.

\section{Discussion}

Maternal and fetal morbidity and mortality from placenta previa and placenta accreta present a challenge to the obstetricians. and are associated with high demands on health resources. With the rising incidence of caesarean sections combined with increasing maternal age, the number of cases of placenta praevia and its complications, will continue to increase [10]

The aim of this study was to evaluate the incidence of placenta previa and accreta in the period from January 2016 to December 2016, and to evaluate the maternal and neonatal outcomes.

The study was a retrospective descriptive study.

The study was conducted at Women's Health Hospital, Assuit University over the period from January 2016 to December 2016.
In the present study the incidence of placenta previa was $1.98 \%$ that is higher than which reported $0.4 \%$ [4] . Also the incidence of placenta accreta was $0.4 \%$ also higher than which reported $1 / 533$ deliveries [6]. This alarming increase appears to be directly related to the rising rates of Cesarean delivery also this risk increase with increase number of cesarean section.

In the present study 267 cases $(94.0 \%)$ received blood transfusion intra operativly, there were some cases needed up to 25 units of blood. The present finding were similar to that of [11], who reported that approximately $75 \%$ of patients required blood transfusion with a mean of $5.4 \pm 2.1$ units of RBCs [11]. Thus, blood transfusion should be anticipated, and massive transfusion is not rare in these obstetric disasters.

In our study ICU admission needed in 35 cases (7.09\%), this is in agreement with [7] who reported that ICU admissions are high in patients with placenta previa and accreta.

In our study bladder injury was occurred in 33 cases $(12.36 \%)$. Also ureteric injury occurred in 3 cases $(1.1 \%)$. Also we reported one case $(0.37 \%)$ of colonic injury. Also we reported one case $(0.37 \%)$ of vascular injury, that is in agreement with [12] who reported that surgical complications such as cystotomy, ureteric and vascular injury are more with placenta accreta.

In the present study, the placenta left in situ in one case of placenta previa accreta. This case ended by post-operative uterine sepsis and ended by hysterectomy, this is in contrast that of [13] who reported that conservative management with leaving placenta in situ is an option and may decrease blood loss and other perioperative morbidity in select patients, and in agreement with [14] who choose to go ahead with a hysterectomy and reserve this management option only for patients who have minimal blood loss and strongly desire fertility preservation.

In our study transverse B Lynch was performed in 10 cases (3.75\%) 5 cases of them needed blood transfusion post-operatively, 4 cases admitted to ICU, one case complicated by post-operative pelvic hematoma, these results are consistent with the study of [15] who reported that transverse B-Lynch sutures are also effective in controlling bleeding from placenta accreta cases. The new modification of B Lynch by making horizontal sutures passed in a vascular area in the broad ligament make more tension around and pressure in the lower segment 
so the technique easily applied to placenta previa and accreta.

In our study intra uterine balloon insertion plus uterine artery ligation were performed in 6 cases $(2.25 \%)$. All of them needed blood transfusion post-operatively \& post-operative internal hemorrhage and re exploration occurred in 2 cases. Also there is one case need admission to ICU, and this is consistent with [17-19]. Who reported that intrauterine balloon tamponade is another minimal to noninvasive procedures in treatment of intra operative and postpartum hemorrhage and preserve the uterus.

In our study uterine artery ligation was performed in 166 cases $(62.1 \%)$, this is in agreement with many authors who advocate routine uterine artery ligation in placenta accreta $[\mathbf{1 9 , 2 0 ]}$ compared bilateral uterine artery ligation with a new compression suture of lower uterine segment and reported shorter operative time and less blood loss with bilateral uterine artery ligation. Another study done at Tanta University Hospital which reported $100 \%$ success of double uterine artery ligation in management of placenta accreta [21]. Others reported no value for this ligation [22].

In our study cesarean hysterectomy was performed in 37 cases $(13.86 \%$ ), that is similar to that reported by [23] who found that hysterectomy is the most commonly performed procedure for the control of obstetric haemorrhage. 27 cases (48\%) of them needed blood transfusion post-operatively, 3 cases $(5.3 \%)$ of them complaining of post-operative internal hemorrhage and need reoperation, one case suffered from post partum hemorrhage. 21 cases $(37.5 \%)$ admitted to ICU, this is in agreement with the study of [7] who reported postoperatively, febrile complications and bowel dysfunction are relatively frequent. Also maternal mortality occurred in 3 cases $(5.3 \%)$, this rate was more than that of [23] who reported rate of $1.0 \%$, whereas other studies have described perioperative death rates of $1-6 \%[24,25]$.

In our study re-operation was required in 8 cases $(2.9 \%)$, this is in agreement with [6] who reported that maternal morbidity as re-operation is high in patients with placenta accerta.

In our study radiological internal iliac artery embolization was performed only in 4 cases $(1.5 \%)$ this is consistent with $[\mathbf{2 6 , 2 7 ]}$ who reported that internal iliac artery embolization is beneficial to decrease the morbidity associated with placenta accreta. In this study we founda limited use of this procedure, that is because this procedure requires high medical costs and sophisticated facilities [28]

In our study maternal mortality occurred in 4 cases $(7.2 \%)$ of cases of placenta accreta, this is greater than which reported by [29] who found that maternal mortality rate in cases of placenta previa was $0.3 \%$ and about $7 \%$ in cases of placenta accreta. That is may be due to the improper preparation for cases and may be due to most of cases come in an emergency state and the operation done by non experience doctor, also may be due to the delayed decision to do hysterectomy.

In our study, the mean gestational age was $34.73 \pm 2.8$ weeks. Also there were 61 neonatal cases $(22.8 \%)$ needed assisted ventilation in the form of ambu bag or endotrachial intubation gestation. NICU admission needed in 41 neonatal cases $(15.4 \%)$, and neonatal mortality reported in 7 neonatal cases $(2.6 \%)$, and this is in agreement with [7] who reported that perinatal complications are increased in cases of placenta previa and accreta due to preterm deliveries.

In our study congenital anomalies were reported in one neonatal case $(0.4 \%)$. This is smaller than what is reported by () who found $6.2 \%$ of women with placenta previa delivered a singleton infant with a major congenital malformation, compared with $3.8 \%$ of unaffected women. This is may be due to the sample size that was insufficient to detect the actual rats of congenital anomalies in these obstetric patients.

\section{References}

1- FARANESH R., SHABTAI R., ELIEZER S. and RAED S.: "Suggested approach for management of placenta percreta invading the urinary bladder," Obstetrics and Gynecology, 110 (2): 512-5, 2007.

2- DASKALAKIS G., ANASTASAKIS E., PAPANTONIOU N., MESOGITIS S. and THEODORA M.: "Emergency obstetric hysterectomy," Acta Obstetricia et Gynecologica Scandinavica, 86 (2): 223-7, 2007.

3- JOHN T. QUEENAN M.D., CATHERINE Y., et al.: Placenta previa and related placental disorders. Published Online: 4 Jan. 2012 and Sons, Ltd, 2012.

4- KIM L.H., CAUGHEY A.B., LAGUARDIA J.C., et al.: Racial and ethnic differences in the prevalence of placenta previa. J. Perinatol., Apr., 32 (4): 260-4, 2012.

5- ANANTH C.V., SMULIAN J.C. and VINTZILEOS A.M.: The effect of placenta previa on neonatal mortality: A population-based study in the United States, 1989 through 1997. Am. J. Obstet. Gynecol., 188: 1299, 2003b, 2003.

6- American Congress of Obstetricians and Gynecologists (2011 \& 2015): Placenta accreta. Committee Opinion No. 266, January 2011 reaffirmed 2015. 
7- WU S., KOCHERGINSKYM. and HIBBARD J.U.: Abnormalplacentation: Twenty-year analysis. Am. J. Obstet. Gynecol., 192 (5): 1458-61, 2005.

8- ELLER G., PORTER T.T., SOISSON P., et al.: Optimal management strategies for placenta," An International Journal of Obstetrics and Gynaecology, 116 (5): 648-54, 2009.

9- SHIROU BEKKU, NOBUAKI MITSUDA, KAZUHIDE OGITA, et al.: High incidence of Respiratory Distress Syndrome (RDS) in infants born to mothers with placenta previa Article first published online: 24 MAY 2000, Doi: 10.1002/(SICI)1520-6661(200003/04)9:2<110::AIDMFM4>3.0. CO;2-5Copyright (C) 2000 Wiley-Liss, inc, 2000.

10- VIJAYA KANCHERLA, SARI RÄISÄNEN, MIKA GISSLER, et al.: Placenta previa and risk of major congenital malformations among singleton births in Finland Article first published online: 24 Mar. 2015, Doi: 10.1002/ bdra.23371, 2015.

11- Royal College of Obstetrics and Gynecology: Green top Guideline No. 27 revised 2015: Placenta previa, placenta previa accreta and vasa previa diagnosis and management, 2011.

12- WARSHAK C.R., RAMOS G.A. and ESKANDER R.: Effect of predelivery diagnosis in 99 consecutive cases of placenta accreta. Obstet. Gynecol., 115 (1): 65-9, 2010.

13- ROSENBERG C.S., GILBERT S., LANDON M.B., et al.: The frequency and complication rates of hysterectomy accompanying cesarean delivery. Obstet. Gynecol., 114: 224-9, 2011.

14- SENTILHES L., AMBROSELLI C., KAYEM G., et al.: Maternal outcome after conservative treatment of placenta accreta. Obstet. Gynecol., 115: 526-34, 2010.

15- TIMMERMANS S., VAN HOF A.C. and DUVEKOT J.J.: Conservative management of abnormally invasive placentation. Obstet. Gynecol. Surv., 62: 529-39, 2007.

16- ELSAYED D.A.: New Modified Cross B-Lynch Versus Classic B Lynch in Controlling Postpartum Hemorrhage. International Journal of Science and Research, 4 (5): 6006, 2015.

17- CANONICO S., et al.: Placenta Previa Percreta: ACase Report of Successful Management via Conservative Surgery. Case Reports in Obstetrics andGynecology, p. 1-3, 2013.

18-DANISMAN N., et al.: The outcomes of surgical treatment modalities to decrease "near miss" maternal morbidity caused by peripartum hemorrhage. European Review for Medical and Pharmacological Sciences, 18: p. 1092-7, 2014.

19- CHO H., et al.: Efficacy of Intrauterine Bakri Balloon Published: August 11, 2015, Doi: 10.1371/journal.pone. 0134282, 2015.
20- SHABANA A., FAWZY M. and REFAIE W.: Conservative management of placenta percreta: A stepwise approach. Arch. Gynecol. Obstet., 291 (5): 993-8, 2015.

21- SHERIF A-EM-EL-SHAZLY, AHMED-Y-BADEE and MOHAMMED-K-ALI: The use of multiple 8 compression suturing as a novel procedure to preserve fertility in patients with placenta accreta: Case series. Aust. N. Z. J. Obstet. Gynaecol., 52 (4): 395-9, 2012.

22- SHEHATA A., HUSSEIN N., EL-HALWAGY A. and EL-GERGAWY A.: Could Simple Procedures Minimize Hysterectomy in Management of Placenta Accreta? Indian Journal of Obstetrics and Gynaecology Research, 2 (4): 213-7, 2015.

23- IWATA A.1., MURAYAMA Y., ITAKURa A., et al.: Limitations of internal iliac artery ligation for the reduction of intraoperative hemorrhage during cesarean hysterectomy in cases of placenta previa accreta. J. Obstet. Gynaecol. Res., 36 (2): 254-9, 2010.

24- WRIGHT J.D., PRI-PAZ S., HERZOG T.J., SHAH M., BONANNO C., et al.: Predictors of massive blood loss in women with placenta accreta. Am. J. Obstet. Gynecol., 205: 38e1-6, 2011.

25- YUCEL O., OZDEMIR I., YUCEL N. and SOMUNKIRAN A.: Emergency peripartum hysterectomy: A 9-year review. Arch. Gynecol. Obstet., 274: 84-7, 2006.

26- WRIGHT J.D., DEVINE P., SHAH M., et al.: Morbidity and mortality of peripartum hysterectomy. Obstet. Gynecol., 115: 1187-93. Cross Ref., Web of Science ${ }^{\circledR}$ Times Cited: 28, 2010.

27- DILAURO M.D., DASON S. and ATHREYA S.: Prophylactic balloon occlusion of internal iliac arteries in women with placenta accreta: Literature review and analysis. Clin. Radiol., 67 (6): 515-20, 2012.

28- D'SOUZA D.L., KINGDOM J.C., AMSALEM H., et al.: Conservative Management of Invasive Placenta Using Combined Prophylactic Internal Iliac Artery Balloon Occlusion and Immediate Postoperative Uterine Artery Embolization. Can. Assoc. Radiol. J., 66 (2): 179-84, 2015.

29- FIGO Guidelines: Committee, S: Prevention and treatment of postpartum hemorrhage in low-resourcesettings. International Journal of Gynecology and Obstetrics, 117: p. 108-18, 2015

30- KIM T.H., LEE H.H. and KWAK J.J.: Conservative management of abnormally invasive placenta: Choriocarcinoma with uterine arteriovenous fistula from remnant invasive placenta. Acta Obstet. Gynecol. Scand., 92 (8): 989-90, 2013

31- KANCHERT V., RAISANEN S., GISSIER M., et al.: Placenta previa and risk of major congenital malformation among singltone births in Finland Birth, 2015.

32- Defects. Res. A. Clin. Mol. Teratol., Jun., 103 (6): $527-$ 35, 2015. 


\section{ملى إستيعاب مستشفى صحة المرآة الجامعى بآسيوط

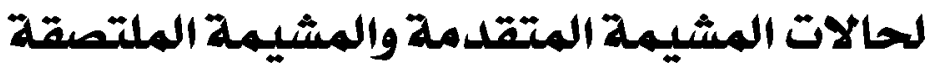

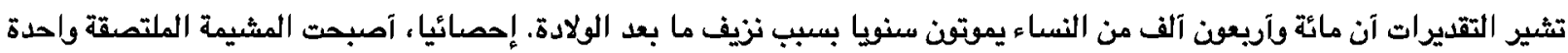

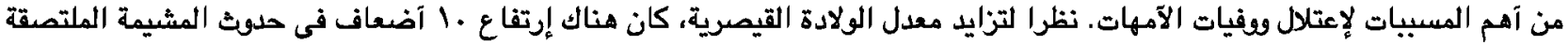
منذ عام .19V. في دراسة حديثة، وجد آن المشيمة الملتصقة قد آصبحت السبب الرئيسي لإستئصال الرحم الطارئ بعد الولادة والتى تمثل • ع- ـج٪ من

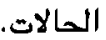
معدل حدوث المشيمة المتقدمة يصل تقريبا إلى ع.. ٪ ويصل معدل الوفيات المصاحب لها إلى ؟ ...٪. تهدف هذه الدراسة إلى معرفة معدل الإصابة بالمشيمة المتقدمة والملتصقة بمستشفى صحة المرآة الجامعى بآسيوط فى عام 17 ـ ومدىى تآثيرها على الآم والطفل.

وقد آظهرت الدراسة النتائج التالية: • معدل الإصابة بالثيمة المتقدة هو 9 .1\% والملتمقة ع . ٪\%. مما يظهر آنه في آكثر من المعدلات المسجلة عالميا. علد حالات المشيمة المتقدمة كان من خلال عام الدراسة rVT حالة. • نزف شديد آثناء الجراحة حدث في باء حالة (rr.\%).

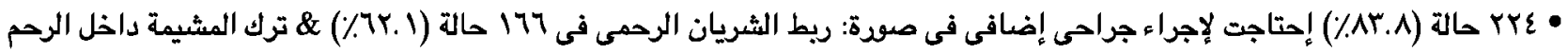

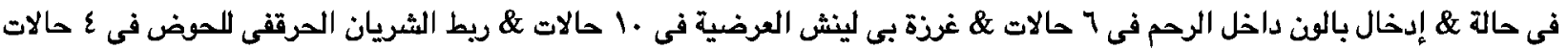
\& \& إستئصال اللرحم في \&

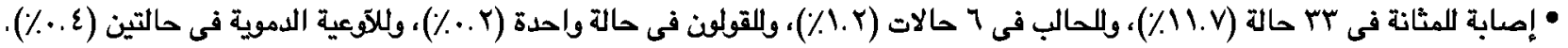

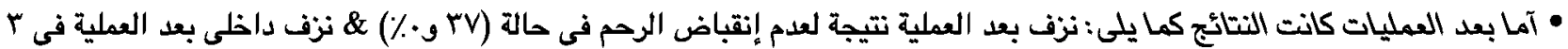

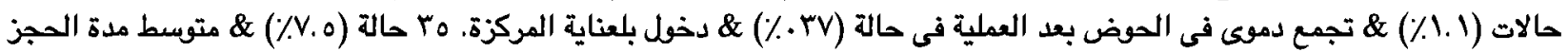

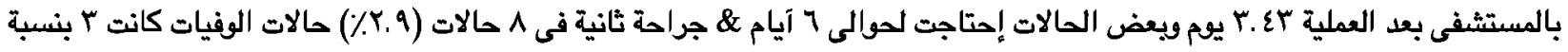

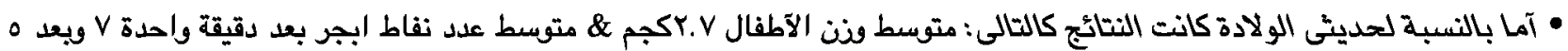

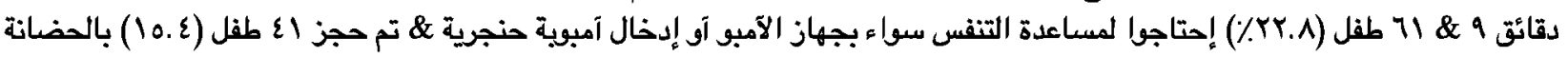

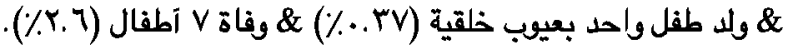
مما سبق ذكره آظهرت النتائج آن معدل الإصابة بالمشيمة المتقدمة والمشيمة الملتصقة فى تزايد وذلاك بسبب التسرع فى إجراء العمليات القيصرية وعلم محاولة إجراء ولادة طبيعية في وجود قيصرية سابقة. 